Studia Philosophiae Christianae

UKSW

$51(2015) 3$

WOJCIECH WIERZEJSKI

\title{
SUMIENIE A PRAKTYCZNA RACJONALNOŚĆ. JAK POGODZIĆ TRADYCYJNE UJECCIE SUMIENIA Z ROSZCZENIAMI DO NIESKRĘPOWANEJ WOLNOŚCI?
}

Streszczenie: Współcześnie można zaobserwować pewien paradoks. Z jednej strony wiele słyszy się o wolności sumienia, więźniach sumienia, konflikcie sumienia, klauzuli sumienia. Z drugiej zaś sumienie jest powszechnie ignorowane, przynajmniej w filozofii. Inny rodzaj paradoksu jest następujący: sumienie, które częstokroć w historii jawiło się jako sprzymierzeniec wszystkich walczących przeciw bezprawiu (tj. przeciw złemu prawu stanowionemu, natomiast w obronie niepisanego prawa naturalnego) i przeciw arbitralności tyranów (tj. tych, którzy realizowali „wolę mocy”), dziś stawiane jest w opozycji wobec obiektywnego prawa moralnego, albo jako racja usprawiedliwiająca wybór po linii zła moralnego. Filozof ma obowiązek zadać pytanie: dlaczego tak sie dzieje? Artykuł poświęcony jest zagadnieniu sumienia. Na początku przypomniana zostaje tradycyjna (tomistyczna) dystynkcja: intentio, synderesis i conscientia. Sumienie zostaje wprowadzone jako schemat syntetyzujący teorię praktycznej racjonalności (pochodzącej od Arystotelesa) i koncepcję wolnej woli (Augustyńską). Duch ludzki doświadcza szczególnego napięcia pomiędzy wezwaniem do posłuszeństwa absolutnym i obiektywnym wymogom prawa naturalnego a skłonnością do niezależności płynącą z doświadczenia własnej indywidualności. Veritatis Splendor pomaga wyjaśnić owe różne typy paradoksów.

Słowa kluczowe: etyka, sumienie, wolność, praktyczna racjonalność, Jan Paweł II, św. Tomasz

\footnotetext{
Wojciech Wierzejski Fundacja Centrum Rozwoju Społecznego i Obywatelskiego w.wierzejski@uksw.edu.pl Solec 81B/73A, 00-382 Warszawa
} 
1. Sieć paradoksów. 2. Klasyczna teoria sumienia. 3. Powrót teorii Akwinaty w Veritatis splendor. 4. Podsumowanie: wzór św. Tomasza Morusa.

Współczesne społeczeństwa funkcjonują w warunkach wielości kultur i - w zasadzie niekwestionowanego - pluralizmu, przynajmniej w świecie Zachodu. Sumienie, które nierzadko w dziejach stawało się wiernym sojusznikiem wszystkich walczących z bezprawiem (czyli prawem stanowionym wbrew prawu naturalnemu) i przeciw arbitralnym decyzjom tyranów (czyli realizacji ich ,woli mocy”), dziś prezentowane jest jako stojące w opozycji wobec obiektywnego porządku moralnego, a z drugiej strony jako racja uzasadniająca wybory idące po linii zła moralnego. Skąd ta zmiana? Czy wynika ona jedynie z transformacji powszechnie akceptowanej koncepcji sumienia? A może ze zmiany w rozumieniu wolności? Pytania o wzajemne relacje pomiędzy sumieniem a wolnością formują na gruncie etyki zagadnienia: prawa naturalnego, autonomii sumienia, rozumu praktycznego, odpowiedzialności podmiotu za wybór dobra/zła moralnego i wiele innych. Dotykamy najbardziej fundamentalnych kwestii etycznych, dyskutowanych od wieków.

W niniejszym artykule podjęte zostanie zagadnienie sumienia w kontekście jego autonomii i w relacji do prawdy i moralnego dobra. $\mathrm{Na}$ początek przypomniane zostanie tradycyjne (tomistyczne) rozróżnienie: intentio, synderesis i conscientia. Sumienie w tej koncepcji wpisane jest w schemat syntetyzujący: $\mathrm{z}$ jednej strony teorię praktycznego rozumowania (pochodzącą od Arystotelesa), z drugiej zaś koncepcję wolnej woli (augustyńską). W duszy ludzkiej od początku napotykamy swoiste napięcie między posłuszeństwem względem absolutnych i obiektywnych wymogów prawa naturalnego a skłonnością do niezależności, opartą na swoistym doświadczeniu jednostki, co więcej - jednostki wpisanej w pewien konkretny kontekst społeczny, kulturowy i historyczny. Jakaś część sumienia (ściślej: synderesis) pozostaje niezmiennie „świadoma” różnicy między dobrem a złem, podczas gdy inna (conscientia) może utracić zdolność fundamentalnego odróżniania dobra i zła. W dalszej części artykułu podjęta zostanie próba wykazania, że teoria moralna Jana Pawła II, zawarta m.in. w Veritatis splendor, adekwatnie opisuje kondycję współczesnych debat na temat miejsca i roli sumienia 
w kształtowaniu się ładu moralnego, a jednocześnie trafnie charakteryzuje błędy wielu współczesnych teorii etycznych, które rażąco wypaczyły pojęcie sumienia, czyniąc z niego instancję legitymizującą nieskrępowaną wolność.

\section{SIEĆ PARADOKSÓW}

Wsłuchując się w przekazy medialne informujące nas o różnych wydarzeniach i zjawiskach społecznych, możemy dostrzec pewien paradoks. Z jednej strony wiele się mówi o: wolności sumienia, więźniach sumienia, konfliktach sumienia, klauzulach sumienia ${ }^{1}$. Pojęcie sumienia nie jest zatem zapomniane, wręcz przeciwnie, pojawia się dosyć często i to w dodatku w wielu politycznych, społecznych, medycznych i innych, nie tylko etycznych kontekstach. Z drugiej jednak strony, jak twierdzi Douglas C. Langston, amerykański filozof z Florydy, sumienie jest ignorowane, przynajmniej w świecie filozofów: „Chociaż używamy sumienia w kierowaniu naszymi zachowaniami i powołujemy się na wolność sumienia w rozmaitych sytuacjach, w ostatnich dwudziestu pięciu latach niewiele zostało napisane na temat sumienia jako

1 Istnieje wiele przypadków, w których lekarze powołują się na klauzulę sumienia: wspomagany medycznie rozród, zastępcze macierzyństwo, ,produkcja” embrionów i ich selekcja, antykoncepcja i aborcja. Na gruncie prawa polskiego, zgodnie z przepisem art. 39 Ustawy o zawodzie lekarza i lekarza dentysty z 5 grudnia 1996 ,lekarz może powstrzymać się od wykonania świadczeń zdrowotnych niezgodnych z jego sumieniem, z zastrzeżeniem art. 30, z tym że ma obowiązek wskazać realne możliwości uzyskania tego świadczenia u innego lekarza lub w innym zakładzie opieki zdrowotnej oraz uzasadnić i odnotować ten fakt w dokumentacji medycznej. Lekarz wykonujący swój zawód na podstawie stosunku pracy lub w ramach służby ma ponadto obowiązek uprzedniego powiadomienia na piśmie przełożonego". Przepis ten interpretuje się jako otwarcie możliwości powołania się na klauzulę sumienia. Na gruncie prawa USA klauzula sumienia została wprowadzona przez rząd George’a W. Busha w 2009 roku. Zakazuje ona instytucjom medycznym otrzymującym wsparcie władz federalnych karania bądź dyskryminowania lekarzy, którzy ze względu na swe przekonania odmawiają wykonania aborcji czy wypisania skierowania na taki zabieg lub recepty na środki antykoncepcyjne. 
użytecznego narzędzia analizy”’2. Skąd ten brak zainteresowania wśród filozofów? Można w pierwszej kolejności wskazywać na okrucieństwa dwudziestego wieku jako rację przemawiającą na rzecz porzucenia pojęcia sumienia. Groza Holocaustu, wielki głód na Ukrainie ${ }^{3}$,„Archipelag GUŁag", apartheid w RPA, czystki etniczne na Bałkanach i w Rwandzie - wszystkie te przerażające świadectwa nikczemności człowieka zdają się dowodzić, że gatunek homo sapiens nie posiada jakiejś swoistej duchowej siły kierującej w sposób niezawodny ku moralnemu dobru. Drugim powodem porzucenia pojęcia sumienia na gruncie filozofii jest zapewne trwające już niemal dwa wieki utożsamienie sumienia z jakimś zbiorem zasad postępowania i niczym więcej. To obniża jego rangę i czyni mało atrakcyjnym. Zasady są - jak wiemy - z natury arbitralne. Nikt nie lubi zewnętrznych, narzucanych zasad.

W naszych czasach możemy jednakże zauważyć występowanie jeszcze jednego paradoksu. A mianowicie, sumienie, które często w historii służyło jako wierny sojusznik wszystkim walczącym przeciwko bezprawiu (czyli tak naprawdę przeciwko niegodziwemu prawu świeckiemu) oraz przeciwko arbitralnym decyzjom tyranów (czyli tym, którzy stosowali w praktyce własną, ,wolę mocy”), dziś jest prezentowane jako stojące w opozycji wobec obiektywnego prawa moralnego, jako racja usprawiedliwiająca wybory zła. Filozof w takiej sytuacji ma obowiązek zapytać: jak to się stało? Tezą główną niniejszego artykułu jest, że Veritatis splendor dostarcza zadowalającej odpowiedzi na to pytanie,

2 D.C. Langston, Conscience and other virtues. From Bonaventure to MacIntyre, The Pennsylvania State University Press, 2001, 1.

3 Według szacunków historyków (por. N. Davies, Europa, Kraków 1999, 1024) świadoma polityka władz ZSRR doprowadziła do śmierci 6-7 milionów Ukraińców w latach 1932-33; natomiast wskutek trzech klęsk głodu w latach 1921-1947, życie straciło około 10 milionów mieszkańców Ukrainy. Dla ludzi ze wsi jedynym miejscem, gdzie można było coś znaleźć do jedzenia było pole kołchozowe. Mołotow i Kaganowicz na rozkaz Stalina opracowali dekret „O ochronie mienia przedsiębiorstw państwowych, kołchozów, spółdzielni oraz wzmocnieniu własności społecznej”. Opublikowany 7 sierpnia 1932 roku nazywany był potocznie ,,prawem pięciu kłosów”, gdyż za zerwanie takiej liczby groziła kara śmierci lub 10 lat łagru. Na mocy tego dekretu skazano ponad 125 tysięcy osób. 
a jednocześnie pomaga wyjaśnić źródła i kontekst owych dwóch wspomnianych paradoksów.

\section{KLASYCZNA TEORIA SUMIENIA}

Św. Tomasz, jak wiadomo, dokonał w filozofii praktycznej syntezy stanowiska Augustyńskiego z Arystotelesowskim. Alasdair MacIntyre, amerykański etyk i historyk filozofii, podkreśla cztery zasadnicze rozbieżności w koncepcjach Stagiryty i biskupa Hippony, których św. Tomasz miał świadomość, a które mogły mieć wpływ na wypracowanie Tomaszowej koncepcji sumienia ${ }^{4}$. Pierwsza dotyczy faktu, że sprawiedliwość u Arystotelesa podlega instytucjonalizacji w postaci praw polis, zaś najlepszy rodzaj Arystotelesowskiego polis bardzo odbiega od Augustyńskiej Civitas Dei. Obywatele polis zasadniczo różnią się pod względem swych moralnych zdolności od ,z natury” niezdolnych do życia w polis barbarzyńców; ponadto praw obywatelskich pozbawione są kobiety i niewolnicy. Tymczasem prawo Civitas Dei jest prawem obejmującym całą ludzkość i każdy człowiek może być rozliczany ze znajomości jego podstawowych przepisów. Nikt też nie jest z góry wykluczony z Civitas Dei, chyba że za sprawą własnych wyborów. Druga rozbieżność polega na tym, że Augustyński zestaw cnót i ogólnie - treść cnót, w istotny sposób różnią się od ich arystotelesowskich odpowiedników. Przykładowo Arystoteles nie znajduje wśród cnót miejsca dla pokory czy życzliwości. Augustyn twierdzi, że bez pokory i życzliwości niemożliwa jest cnota sprawiedliwości. Prawo Civitas Dei domaga się objęcia pewnymi zasadami sprawiedliwości ludzi nienarodzonych, podczas gdy Arystoteles proponował, by odgórnie kontrolować liczbę ludności w polis i odmawiał nienarodzonym jakichkolwiek praw. Co więcej, najdoskonalszym typem człowieka jest, według Arystotelesa, człowiek wielkoduszny, podczas gdy najdoskonalszym typem człowieka według każdej chrześcijańskiej koncepcji (w tym augustyńskiej) jest święty. Trzeci obszar rozbieżności dotyczy tego, że Arystoteles pojmuje związek człowieka z dobrem i z tym, co najlepsze, oraz z tym, co

4 A. MacIntyre, Czyja sprawiedliwość? Jaka racjonalność?, tłum. i red. naukowa A. Chmielewski, Warszawa, 2007, 242-243. 
stanowi dla każdego jego bezpośrednie dobro w perspektywie określonej psychologii, która posługuje się takimi pojęciami, jak rozum, namiętność i pożądanie, ale w której nie ma jednak miejsca dla woli. Z kolei, według Augustyna, to właśnie zła wola (mala voluntas) nie pozwala nam osiągnąć dobra. Jedynie przez zmianę kierunku, w którym dąży wola, możemy ponownie obrać dobro za cel. Czwartą wreszcie kwestią zdecydowanie różniącą oba stanowiska jest to, że fundamentem Augustyńskiej teorii moralnej i w ogóle całej jego myśli jest biblijna wizja więzi, która łączy Boga i duszę. Dusza jest przez Boga stworzona i wezwana, aby przestrzegała Jego sprawiedliwego prawa. Jako taka, jest przeznaczona do życia wiecznego we wspólnocie z Nim. Tymczasem w etyce i polityce Arystotelesa, nie ma miejsca dla boskiego prawodawcy, ani nie ma miejsca na telos, który kierowałby człowieka poza i ponad to, co mogą osiągnąć śmiertelnicy.

Dopiero w kontekście tej szerokiej kontrowersji między oboma stanowiskami rysuje się wielkość Tomasza, który przełamał antyarystotelesowy opór średniowiecznych zwolenników Augustyna. W obliczu tych różnic rysują się także pierwsze rozbieżności między Arystotelesem a Akwinatą, które nie mogą być pokonane z przyczyn zasadniczych: św. Tomasz reprezentuje chrześcijański teizm i wierny jest Augustyńskiej teologii w tej materii. Kluczową różnicą dzielącą Arystotelesa i Tomasza jest pogląd tego ostatniego, że zdecydowanie najważniejszym doświadczeniem, jakie przydarza się istotom ludzkim w odniesieniu do Bożego prawa, czy to takiego, jakie odkrywa rozum, gdy poznaje wskazania prawa naturalnego, czy też objawionego bezpośrednio przez Boga w Dziesięciu Przykazaniach, jest doświadczenie nieposłuszeństwa wobec tego prawa. Tego fundamentalnego nieposłuszeństwa nie da się wytępić nawet przez najlepsze wychowanie zgodne z rozumem. Poszczególne przypadki takiego nieposłuszeństwa wynikają albo ze znieprawienia rozumu wskutek jakiejś namiętności, albo ze złego nawyku, albo ze złego usposobienia natury ${ }^{5}$. Niezdolność do wyrugowania skłonności do nieposłuszeństwa spośród naszych naturalnych i racjonalnych dążeń wskazuje na to, że zło moralne wiąże się z wolą, która jest wolna i nie tylko może wybrać czynienie zła, ale może nadać

\footnotetext{
5 Tomasz z Akwinu, Summa teologii, I-IIae, 94, 4.
} 
temu wyborowi trwałość i stanowczość, których by w innym wypadku nie posiadał ${ }^{6}$.

Jedyny ratunek stanowi łaska boska, dlatego Akwinata zmuszony jest stworzyć bardzo szczególną koncepcję praktycznej racjonalności, która, choć w swej ogólnej strukturze jest Arystotelesowska, to zawiera w sobie istotne wątki Augustyńskiej psychologii. (Podobnie Tomasz uczynił z koncepcją cnót, uzupełniając ją o wątki Augustyńskie). Cnoty pojmowane jedynie po Arystotelesowsku nie są zdolne na tyle udoskonalić istoty ludzkiej, aby mogła ona osiągnąć swój telos, dlatego, iż Arystoteles w niewłaściwy sposób pojmował ów telos, ale także dlatego, iż cnoty naturalne mogą udoskonalać człowieka tylko wtedy, gdy zostaną dopełnione i pokierowane przez miłość (caritas), będącą darem łaski.

Św. Tomasz w opracowaniu swej koncepcji korzysta z dość rozbudowanego już wówczas słownika terminów filozoficznych, które nabrały specyficznego znaczenia, pierwotnie zaś były wykorzystywane przez chrześcijańską teologię. W średniowiecznym łacińskim słowniku moralnym funkcjonują trzy terminy o wielkim znaczeniu dla analizy czynów ludzkich: intentio, synderesis i conscientia, rozumiane znacznie bardziej ściśle, niż ich stosowane nowożytne odpowiedniki. Przykładowo Abelard, podzielając pogląd Augustyna, iż to, co pod względem swoich zewnętrznych przejawów jest jednym i tym samym czynem, może być w przypadku jednej osoby wyrazem pychy, w przypadku innej zaś pokory, twierdził, że czyny same w sobie są moralnie obojętne, powinny natomiast być nazywane dobrymi lub złymi w zależności od tego, czy intentio podmiotu zgadza się z prawem Bożym. Filozofowie z kolei, którzy rozważali rozmaite, konkurencyjne poglądy wyjaśniające, w jaki sposób wola może być zła, wykorzystywali rozróżnienie pojęć synderesis i conscientia. Rozróżnienie tych dwóch terminów pojawiło się w komentarzach dotyczących św. Hieronima interpretacji biblijnej historii Kaina. Hieronim utrzymywał, że Kain przez cały czas, gdy czynił zło, miał sumienie, tzn. wiedział, że to, co robi, jest złe. Jednocześnie niektóre osoby czyniące zło mogą z czasem utracić świadomość, że to, co robią, jest złe. Stąd potrzeba rozróżnienia tego, co

6 Tamże, I-IIae, 20, 4. 
nieusuwalne, co trwa nawet w najbardziej zdeprawowanej istocie ludzkiej (synderesis), od samej świadomości dobra i zła, która może zostać utracona (conscientia). Gdy Tomasz przejął od Arystotelesa koncepcję praktycznego rozumowania, a od Augustyna koncepcję zepsutej woli ludzkiej, i połączył te dwie koncepcje w jeden, całościowy, złożony schemat ludzkiego działania, wówczas był zmuszony wykazać, jakie zastosowanie w jego schemacie pojęciowym znajdą intentio, synderesis i conscientia.

Tomasz dowodził, że pierwsze zasady prawa naturalnego są czymś nieusuwalnym i niedającym się ominąć. ,Synderesis w tej perspektywie to naturalna dyspozycja znajdująca swój wyraz w naszym najbardziej podstawowym ujmowaniu tych zasad, ujmowaniu niebędącym rezultatem jakiegokolwiek procesu badawczego, choćby dlatego, że prawdziwość tych zasad jest już zawsze założona w każdej praktycznej aktywności. Dyspozycję tę należałoby chyba zaklasyfikować jako szczególną potencjalność rozumu" ". Synderesis się nie myli. Każdy fałszywy sąd moralny czy praktyczny, który myli dobro ze złem, jest sądem pochodnym, stanowi wynik jakiegoś rozumowania. Aby zastosować podstawowe zasady w konkretnej sytuacji, konieczne są dodatkowe zdolności, tj. zdolność dedukowania z uniwersalnych i ogólnych podstawowych zasad, zasad bardziej szczegółowych, bardziej bezpośrednio odnoszących się do konkretnych typów sytuacji, jak i wyciągania z obu rodzajów zasad konkretnych sądów praktycznych, dotyczących tego, co powinno być uczynione tu i teraz albo w jakimś konkretnym układzie okoliczności, może stać się naszym udziałem. Do tych zdolności stosuje się termin conscientia. I ona może się mylić ${ }^{8}$. Przykładowo wtedy, gdy jej sąd został wyprowadzony z prawdziwej przesłanki (względnie ze zbioru prawdziwych przesłanek) w połączeniu z jakąś fałszywą przesłanką, co prowadzi do fałszywego wniosku.

W innym przypadku, gdy jej sąd został wyprowadzony z prawdziwych przesłanek przez niepoprawne rozumowanie. Istnieją wprawdzie przypadki, gdy conscientia nie może się mylić, na przykład gdy

7 A. MacIntyre, Czyja sprawiedliwość?, dz. cyt., 270; por. Tomasz z Akwinu, Quaestiones Disputatae de Veritate, 16,15.

8 Tomasz z Akwinu, Quaestiones Disputatae de Veritate, 16,2; 17,2. 
rozumowanie dedukcyjne wychodzące od prawdziwych przesłanek ustalonych przez synderesis jest tak bezpośrednie, że nie pozostawia ono miejsca na błąd podczas przechodzenia od przesłanki do wniosku. Pomijając jednak te dwa szczególne typy przypadków, rozpoznanie prawdziwości podstawowych sądów praktycznych nie daje gwarancji, iż będziemy wiedzieć, czego wymaga od nas postępowanie według tych sądów w konkretnych warunkach praktyki życiowej. W związku z tym nawet przed tymi, którzy nigdy nie zapominają o pierwszych zasadach prawa naturalnego, ciągle otwarte są możliwości zasadniczych błędów9

W przypadku św. Tomasza mamy do czynienia z ogólnymi ramami teologicznymi, w które wpisana została zasadniczo Arystotelesowska koncepcja genezy działania, w którą włączono Augustyńską koncepcję

9 Warto podkreślić, że ta interpretacja teorii św. Tomasza, w wersji MacIntyre’a różni się od ujęć zaproponowanych przez niektórych współczesnych tomistów piszących o prawie naturalnym, którzy twierdzą, iż możliwe jest opracowanie autentycznie tomistycznego ujęcia prawa naturalnego bez potrzeby podejmowania kwestii istnienia Boga czy Jego natury albo woli (por. J. Finnis, Natural Law and Natural Rights, Oxford 1980, 48-49). Idąc w ślad za propozycją samego Akwinaty, MacIntyre pokazuje, że religia jest cnotą moralną i stanowi tę część kardynalnej cnoty sprawiedliwości, która dotyczy tego, co należy oddać Bogu jako zasługującemu na cześć, chwałę i uwielbienie. „Ponieważ doskonałe posłuszeństwo prawu naturalnemu wymaga działania zgodnego z cnotą sprawiedliwości uwzględniającego wszystkie jej składniki, więc trudno rozumieć, w jaki sposób ktoś, kto nie wierzy w istnienie Boga oraz w to, że ze względu na swoje przymioty zasługuje On na cześć, chwałę i uwielbienie, mógłby w doskonały sposób być posłusznym wobec prawa naturalnego. W mojej interpretacji poglądów Tomasza z Akwinu ważne jest zatem to, że jego poglądy dotyczące wiedzy praktycznej i rozumowania praktycznego, nie mówiąc już o sprawiedliwości, pojmuję jako zawsze zakładające ten rodzaj racjonalnego poznania Boga, którego przykład stanowią konkluzje rozważań z Prima pars [Summy teologii]" (A. MacIntyre, Czyja sprawiedliwość?, dz. cyt., 275). Jest to odważne przyznanie się MacIntyre'a nie tylko do ,znaturalizowanej”, neoarystotelesowskiej filozofii Tomaszowej, lecz do pełnego, całościowego teistycznego stanowiska tomistycznego, łącznie z ważnymi jego konsekwencjami teologicznymi. Z tego tytułu MacIntyre zostanie poddany surowej krytyce przez takich autorów, jak przyznająca się do arystotelizmu M. Nussbaum, Recoiling from Reason, New York Review of Books 36, no.19, Dec. 7, 1989, 36-41; oraz D.J.M. Bradley, Aquinas on the Twofold Human Good: Reason and Revelation in Aquinas's Moral Science, Washington, D.C. 1997. Zarzucili oni MacIntyre'owi, że to co on uprawia - przynajmniej od czasu przyjęcia opcji tomistycznej - to nie filozofia, lecz teologia chrześcijańska, w pełni uzgodniona ze stanowiskiem religijnym. 
woli oraz takie pojęcia, jak intentio, synderesis i conscientia. Sam sposób, w jaki Tomasz używa pewnych słów łacińskich jako translacji wyrażeń Arystotelesowskich, najdobitniej pokazuje, jak Akwinata wprowadzał elementy Augustyńskie w Arystotelesowski schemat pojęciowy. Od swojego nauczyciela św. Alberta oraz od Roberta Grosseteste, tłumacza dzieł Arystotelesowych, św. Tomasz przejmuje słowo electio jako przekład Arystotelesowskiej prohairesis. Otóż prohairesis stanowi nazwę tego, do czego prowadzi proces namysłu i wyraża konkluzję, do której dochodzi podmiot, gdy rozważa, jakie działania byłoby dla niego dobrze podjąć w danym momencie jako środek bezpośrednio prowadzący do celu stanowiącego przedmiot namysłu. Tomasz rozwija koncepcję Arystotelesa, gdy charakteryzuje prohairesis jako rozumne pragnienie. Podkreśla przy tym, że jedynie pragnienie powściągnięte i kierowane przez właściwy nawyk moralny jest zgodne z rozumem. Prawda natomiast odkrywana jest przez dociekający rozum praktyczny i jako taka utożsamia się z tym, co odpowiada słusznemu pragnieniu w sądzie dotyczącym tego, co powinno się czynić. Tyle że w przeciwieństwie do Arystotelesa, według Akwinaty tym elementem działania, który znajduje wyraz w prohairesis jest akt woli. Wola natomiast jest zawsze wolna w tym sensie, że działa na podstawie przygodnych sądów dotyczących tego, co dobre albo złe, i zawsze jest otwarta wobec jakiegoś innego przygodnego sądu. Przy czym jakaś nieuporządkowana namiętność może ją pobudzić do czynu zamiast wyważonego sądu rozumu. Wola nie jest bowiem poruszana ku jakiemuś celowi przez konieczność.

I tak oto Augustyńska voluntas zostaje wprowadzona w Arystotelesowskie ramy pojęciowe nie tylko w związku prohairesis. „Wola zawsze jest poruszana do działania przez intelekt; nawet w momentach, gdy jej aktywność jest minimalna, pobudzają ją jakieś sądy. Gdy intelekt sądzi, iż jakiś cel jest dobry, wówczas zostaje wzbudzony akt woli nakierowany na ten cel. Tego typu akt woli Tomasz oznacza nazwą 'intentio'. Intentio może być nakierowane na coś, co jest wybierane bezpośrednio jako pewien cel, albo stanowi środek do osiągnięcia jakiegoś innego celu, albo wręcz na wiele różnych celów. To właśnie obecność intentio odróżnia autentyczny akt woli od zwykłego chcenia. Wola musi także 
przyzwolić na użycie środków ocenionych przez intelekt w procesie namysłu jako właściwe"10.

Jeszcze raz warto podkreślić, że Tomaszowa koncepcja woli podąża ściśle za koncepcją Augustyńską, łącząc wolę z miłością. Mówiąc prościej: rozkoszujemy się tym, czego chcemy - chcąc tego i zdobywając to. Tomasz cytuje Augustyńskie ujęcie ,rozkoszowania się” czymś jako „miłosnego przylgnięcia do jakiejś rzeczy ze względu na nią samą"11. Rozkoszowanie się czymś, co zdobyliśmy albo osiągnęliśmy, przewyższa to rozkoszowanie się woli, które jest tylko w stadium zamiaru, zaś jedynie osiągnięcie doskonałego dobra w postaci wizji uszczęśliwiającej sprawi, że rozkosz woli będzie tak wielka, iż w końcu spocznie ona w spokoju ${ }^{12}$. Wówczas to dopiero wola osiągnie ten ostateczny cel, ku któremu od samego początku kierował ją racjonalny umysł. Ten zaś rodzaj rozkoszowania się, którego źródłem będzie ów cel, stanie się najwyższą spośród wszystkich przyjemności.

\section{POWRÓT TEORII AKWINATY W VERITATIS SPLENDOR}

Jan Paweł II ma świadomość, że we współczesnych debatach moralnych reprezentujących różne teorie etyczne nie wszystko uległo regresowi w stosunku do klasycznej wizji chrześcijańskiej. Wiele elementów, takich jak pojawienie się szczególnej wrażliwości na kwestie wolności, większa świadomość ludzkiej godności i wolności religijnej oraz poszanowanie sumienia poszukującego prawdy - uważane jest dziś powszechnie za fundament praw osoby ${ }^{13}$. I to jest zjawisko pozytywne. Ponadto Papież trafnie diagnozuje, że „Ludzkie problemy najszerzej dyskutowane i rozmaicie rozstrzygane we współczesnej refleksji moralnej sprowadzają się wszystkie - choć na różne sposoby - do zasadniczej kwestii: do kwestii wolności człowieka”.

10 A. MacIntyre, Czyja sprawiedliwość?, dz. cyt., 277; por. Tomasz z Akwinu, Suma teologii, Ia-IIae, 8, 2; Ia-IIae 12, 1-4; Ia-IIae 15,1.

11 Tomasz z Akwinu, Suma teologii, Ia-IIae 11,1.

12 Por. Tamże, Ia-IIae 11,3.

13 Por. Jan Paweł II, Veritatis splendor, w: Encykliki Ojca Świętego Jana Pawła II, Kraków 2005, 741; VS 31. 
Jednakże to, co niepokoi, to fakt, że „w niektórych nurtach myśli współczesnej do tego stopnia podkreśla się znaczenie wolności, że czyni się z niej absolut, który ma być źródłem wartości. W tym kierunku idą doktryny, które zatracają zmysł transcendencji lub które otwarcie deklarują się jako ateistyczne. Sumieniu indywidualnemu przyznaje się prerogatywy najwyższej instancji osądu moralnego, która kategorycznie i nieomylnie decyduje o tym, co jest dobre, a co złe. Do tezy o obowiązku kierowania się własnym sumieniem niesłusznie dodano tezę, wedle której osąd moralny jest prawdziwy na mocy samego faktu, że pochodzi z sumienia. Wskutek tego zanikł jednak nieodzowny wymóg prawdy, ustępując miejsca kryterium szczerości, autentyczności, 'zgody z samym sobą', co doprowadziło do skrajnie subiektywistycznej interpretacji osądu moralnego"14.

Papież zauważa, że istnieje związek między tym zjawiskiem a kryzysem wokół zagadnienia prawdy. „Zanik idei uniwersalnej prawdy o dobru, dostępnym poznawczo dla ludzkiego rozumu, w nieunikniony sposób doprowadził także do zmiany koncepcji sumienia: nie jest już ono postrzegane w swojej rzeczywistości pierwotnej, czyli jako akt rozumowego poznania dokonywany przez osobę, która w określonej sytuacji ma zastosować wiedzę uniwersalną o dobru i tym samym wyrazić swój sąd o tym, jaki sposób postępowania należy uznać tu i teraz za słuszny. Powstała tendencja, by przyznać sumieniu jednostki wyłączny przywilej autonomicznego określania kryteriów dobra i zła oraz zgodnego z tym

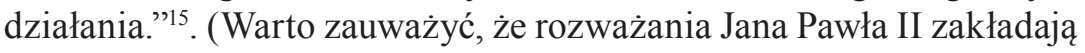
tradycyjną koncepcję sumienia, w wersji wypracowanej przez św. Tomasza z Akwinu. Przywołana w kontekście współczesnych problemów i dylematów moralnych, na nowo jawi się ona jako najbardziej wiarygodna teoria, nic nie tracąca ze swej uniwersalnej prawdziwości). Jan Paweł II dodaje, że przyznawanie sumieniu wyłączności na określanie, co jest dobrem a co złem łączy się ściśle z etyką indywidualistyczną, według której każdy człowiek staje wobec własnej prawdy, różnej od prawdy innych. W Encyklice podsumowane to zostaje jednoznacznie:

\footnotetext{
14 Tamże, 742; VS 32.

15 Tamże, 742-743; VS 32.
} 
„Posunięty do skrajnych konsekwencji indywidualizm, prowadzi do zaprzeczenia samej idei natury ludzkiej"16.

Papież nie ma wątpliwości, że we współczesnej kulturze napotykamy paradoksalną sprzeczność, polegającą na tym, że choć powszechnie przyznaje się dziś tak wielkie znaczenie wolności, zarazem radykalnie ta wolność ulega zakwestionowaniu. Pewne dyscypliny naukowe, szczególnie tzw. „nauki o człowieku”, nieustannie przypominają nam o psychologicznych i społecznych uwarunkowaniach naszego życia, które wpływają na sposób, w jaki człowiek korzysta z wolności. To wartościowa wiedza, która znajduje zastosowanie w różnych dziedzinach życia, na przykład w pedagogice i w wymiarze sprawiedliwości. Ale, jak zauważa Papież: „Niektórzy jednak posuwają się dalej i wychodząc poza uprawnione wnioski, jakie można wyciągnąć z tego rodzaju obserwacji, podają w wątpliwość lub wręcz negują samą realność ludzkiej wolności"17. Podobnie rzecz się ma w dziedzinie antropologii. Tutaj niektórzy naukowcy, powołując się na wielką różnorodność tradycji, obyczajów i instytucji, istniejącą w ramach ludzkiej cywilizacji, dochodzą do relatywistycznej koncepcji moralności, co jest nadużyciem i kolejnym przykładem wychodzenia poza uprawnione wnioski.

\section{PODSUMOWANIE: WZÓR ŚW. TOMASZA MORUSA}

Jan Paweł II w wielu innych miejscach odwoływał się do pojęcia sumienia jako aktu rozumnego poznania, dokonywanego każdorazowo w relacji do prawdy. Najbardziej wymownie uczynił to przywołując postać Tomasza Morusa, którego zresztą uczynił patronem rządzących i polityków ${ }^{18}$. Napisał w specjalnie poświęconym temu świętemu Motu proprio: „Z życia i męczeństwa św. Tomasza Morusa wypływa przesłanie, które dociera poprzez stulecia do ludzi wszystkich czasów i mówi im, że sumienie ma niezbywalną godność, jest bowiem - jak

16 Tamże, 743; VS 32.

17 Tamże, 743; VS 33.

18 Jan Paweł II, List Apostolski «motu proprio» o ogłoszeniu św. Tomasza Morusa Patronem rządzacych i polityków, http://www.opoka.org.pl/biblioteka/W/WP/jan_pawel_ii/listy/tomasz_morus_31102000.html [dostęp:15.02.2014]. 
przypomina Sobór Watykański II - »najtajniejszym ośrodkiem i sanktuarium człowieka, gdzie przebywa on sam z Bogiem, którego głos w jego wnętrzu rozbrzmiewa« (Gaudium et spes, 16). Gdy człowiek jest posłuszny wezwaniom prawdy, sumienie kieruje nieomylnie jego czyny ku dobru"19. Papież wyniósł Morusa do godności patrona polityków ze względu na jego świadectwo o prymacie prawdy nad władzą, składane aż do przelania krwi. Jest on ukazany jako zawsze aktualny wzór wierności wyznawanym zasadom moralnym, albo inaczej: wierności sumieniu. „Człowiek nie może oderwać się od Boga ani polityka od prawdy: oto jest światło, które rozjaśniało jego sumienie" ${ }^{20}$. I właśnie na polu obrony praw sumienia przykład Tomasza Morusa, zdaniem Jana Pawła II, zajaśniał szczególnie mocnym blaskiem: „w bardzo szczególny sposób doświadczał on wartości sumienia"21.

Jest jeszcze jedna cenna lekcja płynąca z życie i męczeństwa Tomasza Morusa, która wyraźnie ukazuje pewną fundamentalną prawdę etyki politycznej. Papież zauważa że: „obrona wolności Kościoła przed nieuprawnionymi ingerencjami państwa jest jednocześnie obroną - podejmowaną w imię prymatu sumienia - wolności człowieka w relacji do władzy politycznej. Zawiera się w tym podstawowa zasada wszelkiego ładu społecznego zgodnego z naturą człowieka"22.

Wielu z nas zapewne zgodzi się, że niewiele zmieniło się od czasów Św. Tomasza Morusa w tej materii. Władza zawsze będzie żywić swoistą totalitarną pokusę do „nieuprawnionych ingerencji”, dlatego zawsze będą potrzebni ludzie sumienia, świadkowie sumienia, a w szczególnych okolicznościach - męczennicy sumienia.

\section{BIBLIOGRAFIA}

Bradley D.J.M., Aquinas on the Twofold Human Good: Reason and Revelation in Aquinas's Moral Science, Catholic University of America Press, Washington D.C. 1997.

\footnotetext{
19 Tamże, 1.

20 Tamże, 4.

${ }^{21}$ Tamże.

22 Tamże.
} 
Davies N., Europa, Wyd. ZNAK, Kraków 1999.

Finnis J., Natural Law and Natural Rights, Oxford 1980.

Jan Paweł II, List Apostolski »motu proprio« o ogłoszeniu św. Tomasza Morusa Patronem rządzacych i polityków, http://www.opoka.org. pl/biblioteka/W/WP/jan_pawel_ii/listy/tomasz_morus_31102000. html; [dostęp:15.02.2014].

Jan Paweł II, Veritatis splendor, w: Encykliki Ojca Świętego Jana Pawła II, Wyd. Znak, Kraków, 2005.

Langston D. C., Conscience and other virtues. From Bonaventure to MacIntyre, The Pennsylvania State University Press 2001.

MacIntyre A., Czyja sprawiedliwość? Jaka racjonalność?, tłum. i red. naukowa A. Chmielewski, Wydawnictwo Akademickie i Profesjonalne, Warszawa 2007.

Nussbaum M., ,,Recoiling from Reason”, New York Review of Books 36, no.19, December 7, 1989, 36-41.

Tomasz z Akwinu, Quaestiones Disputatae de Veritate, wyd. pol. Kwestie dyskutowane o prawdzie tomy I-II, tłum. z łac. L. Kuczyński, A. Aduszkiewicz, J. Ruszczyński, Wydawnictwo Antyk, Kraków 1999. Tomasz z Akwinu, Suma teologiczna, t. 1-34, tłum. z łac. F. W. Bednarski, P. Bełch, A. Głażewski, Veritas, London 1962-1986.

\title{
CONSCIENCE AND PRACTICAL RATIONALITY. HOW TO RECONCILE THE TRADITIONAL CONCEPT OF CONSCIENCE WITH CLAIMS TO UNFETTERED FREEDOM?
}

\begin{abstract}
Summary: We can observe a paradox. On the one hand we hear a lot about: freedom of conscience, prisoners of conscience, conflicts of conscience, conscience clauses. On the other hand conscience has been ignored, at least by philosophers. Another kind of paradox: conscience, which often in history became a staunch ally of all the fighting against lawlessness (i.e. against the evil written law, in defense of the natural law) and against the arbitrariness of tyrants (i.e. against those who apply "will to power"), today is presented as standing in opposition to the objective moral order, or as the reason justifying the choices of moral evil. The philosopher should ask: how did that happen? The paper addresses the issue of conscience. At the beginning it recalls the traditional (Thomistic) distinction: intentio, synderesis and conscientia. Conscience is entered into the scheme synthesizing the theory of practical reasoning (derived from Aristotle) with the concept of free will (Augustinian). The human soul encounters
\end{abstract}


a peculiar tension between obedience to absolute and objective requirements of natural law and the propensity for independence based on the experience of the individual. Veritatis Splendor helps to explain these two types of paradoxes.

Key words: ethics, conscience, freedom, practical rationality, John Paul II, St Thomas 